\title{
Promoting Task-based Autonomous Learning in Intensive listening Class through Elica
}

\author{
${ }^{1}$ Arum Nisma Wulanjani , ${ }^{2}$ Lilia Indriani \\ ${ }^{1,2}$ Universitas Tidar \\ \{1arum_nisma@untidar.ac.id, ${ }^{2}$ indriani@untidar.ac.id\}
}

\begin{abstract}
In this fast-growing digital era, students are sometimes demanded to be autonomous agents toward their own learning. The students need to adapt and custom themselves with the use of technology and gadgets in learning process. The rapid use of technology brings its own benefit in learning process, including in learning listening. Technology, both directly and inderectly, can drag the students to be actively participated in the learning process. When the students are highly participted and in charge in their own learning, it can be seen that they already become autonomous agents or learners. This research is a case study which tries to explore the use Elica website in promoting a task-based autonomous learning in Intensive Listening classes. Task-based is choosen since it has been adopted widely in higher education. Besides, this model seems fit to be applied in Intensive Listening classes which use Elica website. There were 56 students participated in this research. A set of questionnaire and an interview were used in this research. From the result its was found that most of the students belong to autonomous learners and more than $70 \%$ of them were included as independence learners. The presence of Elica website can provide the students with unlimited access in involving themselves in a task-based learning.
\end{abstract}

Keywords - autonomous learning, listening, task-based, Elica

\section{INTRODUCATION}

The existence of technology really give various and significant effect in language teaching area. Nowadays, the use of technology goes beyond the traditional computer assissted language learning. Instead of using technology only as a tool in teaching process, the use of technology is now shifted to be "a hand" which should enable students in triggering and enhancing their learning. Besides, Havriluk (2004) cited by [1] suggests the following for rationalizing the usde of technology in a learning process: i) high motivation; ii) unique instructional capabilities; iii) support for innovative instructional approaches; and iv) increased teacher productivity and students knowledge construction. Thus, the use of technology, especially in a language learning, should present an opportunity for students in enhancing their knowledge capabilities. Dudeney (2007) cited by [1] adds that the use of 
technology is now increasingly mobile. It gives more advantages for students in becoming autonomous learners by having independent and self-access language learning.

Providing students with an autonomous learning can accomodate students to be an effective learner. As stated by [2], the autonomy positively affects language learning and it is no doubt that learner autonomy can increase motivation to learn and learning effectiveness. [3] Learner autonomy needs to be considered because it gives more opportunities for students to be independent in learning. Furthermore, learner autonomy can be elaborated by determining how students are in fulfilling the criteria of learner autonomy, those are selfinstruction, self-direction, self-access learning and individualized instruction (Dickinson in Kumaravadivelu 2003), as cited by [3]. In conclusion, the higher of the students capabilities in fullfiling those criteria, the higher degree of the students' autonomy. This state of the students' autonomy will lead them become successful learners, since autonomous learners hold responsibilities for their own learning [2].

In looking at learner autonomy, the self-access setting can offer learners choices in time, location, and pace of learning; the path through the material to be chosen; and the topics of interest. Technology can play a role in all of these [1]. Moreover, Nowlan as cited by [4] suggests using the internet and technology for having autonomy in language learning. In line with explanation above, this study aims to describe how the use of Elica, which is a customized website for listening learning, can promote an autonomy learning in Intensive Listening classes. Elica itself provides various listening sources for different level of learners. There are various recording and videos presented in Elica. It is chosen because this study holds the concept of autonomy learning, in which self-access is highly considered. Elica allows the students to access the materials at anytime and at anyplace. In addition, Elica provides chances for the students to create tasks and to involve in a task-based listening activity.

A task-based model has been chosen in this study since this model seemed fit to apply in listening learning. The design of a task-based lesson is basically involving a task as a component of lesson [5]. Nunan (1991) in Oura (2001) as cited by [6], states that the focus of task-based language teaching is on engaging students to comprehend, manipulate, produce and interact iin the target language.

Thus, this study tries to utilize the benefits of technology in language learning through the use of Elica website in promoting a task-based autonomous learning for the success of the students in listening learning. By providing a task-based autonomous learning through the use of Elica website and having a task-based activities during the listening learning, the students are expected to be effective and autonomous learners.

\section{METHODOLOGY}

This study is aimed at drawing qualitative conclusion through case study on using Elica to promote a task-based autonomy learning in Intensive Listening classes. This study reported the actual data from the nantural setting. The subjects of this study consisted of 56 students of English Department Universitas Tidar who joined Intensive Listening classes. Two primary techniques of data collection were used in this study, they were questionnaire and interview. A set of questionnaire was distributed through google form. The questionnaire was adapted from [7]. The students were given the links of the google form to access, and then they filled and sent the questionnaire back. The set questionnaire consists of three different questionnaire, the first one is related to the students' autonomy learning stages which include self-planning, self-monitoring and self-evaluation represented by 12 statements with two options 'yes' and 'no'. The second questionnaire investigates the students' use of autonomy 
strategies, which consists of 27 statements with two options 'yes' and 'no', reflecting the students' independence in listening learning. There are 16 statements which reflect independence in learning and 11 statements which refelect dependence in learning. The third questionnaire was constructed to expose the students' attitudes towards the use of Elica website. It consists of 5 questions with two options 'agree' and dissagree'.

On the other hand, the interview itself is an open-ended questions adapted from [8], which reveals the students' perception about the use of Elica in Intensive Listening classes. The data analysis is conducted quantitatively. After gathering the results of questionnaire and interview, all the data then is analyzed quantitatively and comprehensively.

This research had been conducted for seven meetings. It was during the seven regular Intensive Listening meetings. During the times, the students were asked to contribute actively in listening learning activity by using Elica website. Every meeting, different students were chosen to take responsibilities for deciding the materials and the activities through Elica. The questionnaire and interview were given after those seven regular Intensive Listening meetings.

\section{FINDINGS AND DISCUSSION}

The questionnaire and interview were given after the regular Intensive Listening meetings. From the the first questionnaire, which investigates autonomy learning of the students, it reveals the students' profile of autonomy learning. The result of the first questionnaire can be seen in the following table:

Table 1. The Result of Questionnaire on Students' Autonomy Learning

\begin{tabular}{|l|l|c|c|}
\hline No. & \multicolumn{1}{|c|}{ Statements } & Students' & \multicolumn{2}{|c|}{ Response } \\
\cline { 3 - 4 } & & Yes & No \\
\hline & Self-Planning & & \\
\hline 1. & Students' material preparation before the class begin & 52,6 & 47,4 \\
\hline 2. & Students' listening strategies & 59,6 & 40,4 \\
\hline 3. & $\begin{array}{l}\text { Students' activeness in finding the information of the } \\
\text { material }\end{array}$ & 75,4 & 24,6 \\
\hline 4. & Students' sources preparation before the class begin & 59,6 & 40,4 \\
\hline & Self-Monitoring & & \\
\hline 1. & Active in questioning the material & 50,9 & 49,1 \\
\hline 2. & Active in working individually or group & 94,7 & 5,3 \\
\hline 3. & Active in using dictionary and other sources & 94,7 & 5,3 \\
\hline 4. & Active in correcting the task & 78,9 & 21,1 \\
\hline & Self-Evaluating & & \\
\hline 1. & Re-study the material by their own & 68,4 & 31,6 \\
\hline 2. & Re-discuss the material with their friends & 77,2 & 22,8 \\
\hline 3. & Active in asking the difficulty to the teacher & 52,6 & 47,4 \\
\hline 4. & Active in finding the difficulty by themselves & 91,2 & 8,8 \\
\hline
\end{tabular}

From the table above, it can be seen that most of students gave positive responses towards autonomy learning. There are stages which show significant response from the students, they are self-monitoring stage and self-evaluating stage. From self-monitoring stage, the significant responses are shown by the students' activeness in working individually or group and also their activeness in using various sources. It holds $94,7 \%$ of the students who are included of active learners. While from self-evaluating stage, the most significant response is 
shown from the students' activeness in finding their difficulty themselves. There are $91,2 \%$ of the students were able to find their difficulty in listening learning.

The second questionnaire consists of 27 statements, which 16 statements reflect students' dependence in learning and the other 11 statements reflect students' independence in learning. From the second questionnaire, how they reacted to their autonomy learning is shown by the table below.

Table 2. The Result of Questionnaire on the Students' Use of Autonomy Strategies

\begin{tabular}{|c|c|c|c|}
\hline \multirow[t]{2}{*}{ No. } & \multirow[t]{2}{*}{ Statements } & \multicolumn{2}{|c|}{ Students' $_{(\%)}$ Response } \\
\hline & & Yes & No \\
\hline 1 & I usually set my own goal for each semester. & 80,4 & 19,6 \\
\hline 2 & I use other English books and resources on my own will. & 83,9 & 16,1 \\
\hline 3 & $\begin{array}{l}\text { While learning listening, I like activities in which I can learn } \\
\text { on my own. }\end{array}$ & 87,5 & 12,5 \\
\hline 4 & I like trying new things while I am learning listening. & 100 & 0 \\
\hline 5 & $\begin{array}{l}\text { In the future, I would like to continue learning listening on } \\
\text { my own/without a teacher. }\end{array}$ & 78,6 & 21,4 \\
\hline 6 & $\begin{array}{l}\text { In the listening lesson I like projects where I can work with } \\
\text { other students. }\end{array}$ & 67,5 & 12,5 \\
\hline 7 & $\begin{array}{l}\text { I can learn the English on my own/ without needing a } \\
\text { teacher. }\end{array}$ & 37,5 & 62,5 \\
\hline 8 & $\begin{array}{l}\text { If I cannot learn listening in the classroom, I can learn } \\
\text { working on my own. }\end{array}$ & 76,8 & 23,2 \\
\hline 9 & $\begin{array}{l}\text { I like learning English words by looking them up in a } \\
\text { dictionary. }\end{array}$ & 83,9 & 16,1 \\
\hline 10 & $\begin{array}{l}\text { I would like to use cassettes/ video/ CD's in the foreign } \\
\text { language, outside of the classroom. }\end{array}$ & 80,4 & 19,6 \\
\hline 11 & I would like to select the materials for my listening lessons. & 75 & 25 \\
\hline 12 & In fact I like to listen English outside of the classroom. & 78,6 & 21,4 \\
\hline 13 & I know how I can learn listening the best. & 53,6 & 46,4 \\
\hline 14 & $\begin{array}{l}\text { If I haven't learnt something in my listening lesson, I am } \\
\text { responsible for it. }\end{array}$ & 82,1 & 17,9 \\
\hline 15 & I know my weaknesses and go for it. & 82,1 & 17,9 \\
\hline 16 & I have my own ways of testing how much I have learned & 69,6 & 30,4 \\
\hline 17 & $\begin{array}{l}\text { My language learning success depends on what I do in the } \\
\text { classroom }\end{array}$ & 44,6 & 55,4 \\
\hline 18 & $\begin{array}{l}\text { I am afraid that I won't learn a topic if the teacher doesn't explain it } \\
\text { in the listening class. }\end{array}$ & 21,4 & 78,6 \\
\hline 19 & I learn better when the teacher explains something on the board. & 10,7 & 89,3 \\
\hline 20 & $\begin{array}{l}\text { I feel confident when the teacher is beside me while I am learning } \\
\text { listening. }\end{array}$ & 46,4 & 53,6 \\
\hline 21 & I can learn listening only with the help of my teacher. & 80,4 & 19,6 \\
\hline 22 & My teacher always has to guide me in learning listening. & 35,7 & 64,3 \\
\hline 23 & $\begin{array}{l}\text { While learning listening I would like my teacher to repeat } \\
\text { grammatical rules. }\end{array}$ & 8,9 & 91,1 \\
\hline 24 & I feel happy when my teacher explains very detail of English. & 3,6 & 96,4 \\
\hline 25 & I like my teacher to correct my errors when I make a mistake. & 5,4 & 94,6 \\
\hline 26 & I want the teacher to give us the words that we are to learn. & 0 & 100 \\
\hline 27 & $\begin{array}{l}\text { Every time I have an assignment, the teacher should score or correct } \\
\text { it. }\end{array}$ & 1,8 & 92,8 \\
\hline
\end{tabular}


Based on the table above, we can see that most of the students belong to independence learners. The most significant result is shown the state where the students like to try new things in listening learning. All of the students agree that point. Out of 15 statements which reflect independence in learning, there is one condition which reveals that $62,5 \%$ of the students admit that they still need a teacher in istening learning processs. They might not feel confidence to learn their own way without the presence of the teacher. While from 11 statements which reflect students' dependence in learning, there are two conditions which show that the students feel that their success of learning depends on the help from the teacher, it reached $80,4 \%$ of students. It indicates that most of the students still have low confidence that they can learn listening themselves independently.

Table 3. The Result of Questionnaire on the Students' Attitude towards Elica

\begin{tabular}{|l|l|c|c|}
\hline \multirow{2}{*}{ No. } & \multicolumn{2}{|c|}{ Statements } & \multicolumn{2}{c|}{ Students' Response (\%) } \\
\cline { 3 - 4 } & & Agree & Dissagree \\
\hline 1 & & 96,3 & 3,7 \\
\hline 2 & Freedom of choosing when and where to learn & 92,6 & 7,4 \\
\hline 3 & Learner choice of learning materials & 92,6 & 7,4 \\
\hline 4 & Meeting learners' need & 100 & 0 \\
\hline 5 & Interesting learning media & 98,1 & 1,9 \\
\hline
\end{tabular}

From the table above, it is found that almost of the students gave a positive attitude towards the use of Elica website during the listening learning. Most of them agree that Elica website contains of various listening sources, so it will give them more freedom to choose any sources regarding to their personal choice. More than $92 \%$ of the students also think that materials in Elica website meet their need in Intensive Listening course. At one point, all of the students agree that Elica is an interesting media used in listening learning. Lastly, more than $98 \%$ of the students state that they can expose more in listening learning through Elica.

For the interview, there were three questions given for the students. The interview itselt is basically as an affirmation of the students' opinion toward the use of Elica during the listening learning. The questions exposed in the interview were: i) What did you like most about ELICA website?; ii) What have you gained as a result of the use of ELICA website?; and iii) How do you suggest the component of ELICA website could be improved?. The result from the interview has been summarized on the table below.

Table 4. The Summary of the Students' Response from Interview

\begin{tabular}{|c|l|ll|}
\hline No. & \multicolumn{1}{|c|}{ Questions } & \multicolumn{2}{|c|}{ Summary of the Students' Response } \\
\hline 1 & What did you like most about & 1. & Various sources for listening \\
& ELICA website? & $\begin{array}{l}2 . \\
3 .\end{array}$ & Independence and easy use \\
& & Clear voice or sound \\
\hline 2 & What have you gained as a & 1. & Interesting way in listening \\
\hline
\end{tabular}




\begin{tabular}{|c|c|c|}
\hline & $\begin{array}{l}\text { result of the use of ELICA } \\
\text { website? }\end{array}$ & $\begin{array}{l}\text { learning } \\
2 . \text { More opportunity to practice } \\
\text { listening } \\
\text { 3. Improving vocabulary }\end{array}$ \\
\hline 3 & $\begin{array}{l}\text { How do you suggest the } \\
\text { component of ELICA website } \\
\text { could be improved? }\end{array}$ & $\begin{array}{l}\text { 1. Adding more exercises and } \\
\text { questions } \\
2 . \quad \text { Improving the theme and template } \\
\text { of the website } \\
\text { 3. Adding 'delete' and 'edit' buttons } \\
\text { on the reply column. } \\
4 . \quad \text { Adding feedback } \\
5 . \quad \text { Adding 'search' feature } \\
6 . \quad \text { Adding more interesting menus }\end{array}$ \\
\hline
\end{tabular}

At the first place, the purpose of this study is to seek out the students' learning autonomy after having a task-based listening learning by utilizing Elica website as a source. In seeking out it, a aset of questionnaire and an interview has been used in this study. From the result of the questionnaires related to the autonomy learning, it reveals that most of the students are autonomous learners. It reaches $67,53 \%$ of the students who belong to autinolous learners. They have a high result on all three aspects, which are self-planning, self-monitoring, and self-evalutaing. The result indicates that more than $50 \%$ of the students were more responsible for their own learning and had initiatives in finding solution for their problems in listening learning. While from the independence and depence aspects, more than $75 \%$ students were concluded as independence learners. But still there are two areas in which the students were less independence, the presence of the teacher and their dependence on classroom activities cause a worriness for them. They still believe that their success of listening learning depends on the presence of the teacher.

Furthermore, from the result of the students' investigation related to the use of Elica website, more than $90 \%$ of them agree that Elica website can provide them unlimited access in getting sources for listening. They admitted that by using Elica, they can be activelly participated in the listening learning. They can have a freedoom to choose various sources provided by Elice, to create tasks, and to reply to the tasks. Moreover, they agree that Elica is easy to use, free-accees, and it has lots of sources for listening learning. But still some improvement is needed for Elica. By improving the menus, features, and the lsitening practice in Elica, it will improve the the function of Elica as a listening learning source.

\section{CONCLUSION}

This study has revealed that the use of Elica website in promoting a task-based listening learning bring positive feedback from the students. By the help of technology, it can foster them to be more responsible with their learning. Besides, bringing the use of technology in listening learning also can force the students to be independent learners. Being responsible and independent have correlation with autonomy learning, which can lead the students to achieve success in a language learning [4]. Moreover, Elica website can be as a recomended listening source in conducting a task-based listening learning. Still, some improvements are needed for Elica in order to be more reliable source for listening learning. 


\section{References}

[1] L. Budianto, "PROMOTING STUDENTS ' AUTONOMOUS LEARN ING THROUGH ICT BASED LEARNING IN ICP : A CASE STUDY," vol. 9, no. 2, 2014.

[2] A. Sholeh, "Promoting Autonomous Learning in Reading," Jeels, vol. vol, no 2, no. November, pp. 108-121, 2015.

[3] Y. Yuliani and N. S. Lengkanawati, "PROJECT-BASED LEARNING IN PROMOTING LEARNER AUTONOMY,” vol. 7, no. 2, pp. 285-293, 2017.

[4] N. S. Masouleh and R. B. Jooneghani, "Autonomous learning: A teacher-less learning!," Procedia - Soc. Behav. Sci., vol. 55, no. October 2012, pp. 835-842, 2012.

[5] R. Ellis, "The Methodology of Task-Based Teaching," 1993.

[6] K. Motallebzadeh, "The Effect of Task-Based Listening Activities on Improvement of Listening Self-Efficacy among Iranian Intermediate EFL Learners," vol. 5, no. 2, pp. 24-33, 2013.

[7] F. Wulansari, H. Yufrizal, and H. Hasan, "ANALYZING AUTONOMOUS LEARNING AT FIRST GRADE OF JUNIOR HIGH SCHOOL STUDENTS Fitri Wulansari , Hery Yufrizal , Hartati Hasan Ministry of education and culture of Indonesia has already published the new curriculum for Indonesia's education , 2013 curricul."

[8] L. Man and W. Conttia, "The Influence of Learner Motivation on Developing Autonomous Learning in an English-for-Specific-Purposes Course," no. September, 2007. 